\title{
O Mercado de Escravos na Comarca Bananeiras, Província da Paraíba: 1860-1888
}

\section{Dora Isabel Paiva da Costa}

Este artigo trata do mercado de escravos no âmbito estritamente local no município de Bananeiras situado numa região alta do planalto da Borborema, área de transição entre a antiga zona da Mata Atlântica e o sertão paraibano. A região litorânea se especializou, desde a colonização no século XVI, nos engenhos de cana e o sertão na atividade criatória.

A região que ora estudamos teve sua colonização por volta do final do século XVII e início do século XVIII. Bananeiras será elevada à categoria de vila em 1833. Está situada num brejo do agreste e se especializou em culturas de subsistência associadas à plantação de cana em pequena escala. Logo nas primeiras décadas do século passado, começou a produzir algodão. O café será introduzido, também em pequena escala, na segunda metade do século passado. ${ }^{1}$

A historiografia, quando trata do comércio de escravos, sempre focaliza os proprietários de grandes lavouras como as de café e de cana participantes do mercado de cativos.

Este trabalho focaliza o comércio de escravos entre os anos $1860 \mathrm{e}$ 1888. Nosso argumento é mostrar a importância dos senhores de escravos, donos de pequenos e médios plantéis e plantadores de culturas de subsistência, na atividade de compra e venda de cativos, nos arredores da vila em questão.

A partir da tabela 1, pode-se observar a estrutura do mercado de escravos da comarca de Bananeiras. Apresentamos quase três décadas de compra e venda de mancípios. Da amostragem de 207 escrituras, aparecem 249 indivíduos escravos (homens, mulheres e crianças) sendo 
objetos de comercialização. A grande incidência em termos percentuais de compra e venda se deu nas décadas de 1860 e 1870 . Este resultado confirma os resultados colhidos pela historiografia que aponta as décadas de 60 e 70 como de intenso tráfico interprovincial. A década de 80 é apresentada como um marco na mudança de atitudes dos senhores de escravos, tendo em vista eles perceberem o fim iminente da instituição da escravidão no Brasil. O tráfico de escravos só se torna vultuoso a partir da década de 50 , quando o tráfico internacional é interrompido. ${ }^{2}$

\section{TABELA 1}

Ocorrência de compra e venda de escravos na Comarca de Bananeiras, 1860-1888

\begin{tabular}{lccc}
\hline Anos & $\begin{array}{c}\text { Freqüência } \\
\text { das Escrituras } \\
\left(\mathbf{n}^{\circ} \text { absolutos) }\right.\end{array}$ & $\begin{array}{c}\text { Freqüência } \\
\text { dos Escravos } \\
\left(\mathbf{n}^{\circ} \text { absolutos) }\right.\end{array}$ & $\begin{array}{c}\text { Freqüência } \\
\text { Relativa de } \\
\text { Escravos (\%) }\end{array}$ \\
\hline $1860-9$ & 101 & 120 & 48,2 \\
$1870-9$ & 92 & 114 & 45,8 \\
$1880-8$ & 13 & 15 & 6,0 \\
\hline TOTAL & 206 & 249 & 100,0 \\
\hline
\end{tabular}

FONTES: Escrituras de Compra e Venda de Escravos, localizadas nos Livros de Notas: 1860, 1861, 1865-67, 1867-77,1876. $79,1879-84,1884-90$. Esta documentaçáo se encontra no Arquivo do Cartório do Segundo Ofício. Doravante, todas as vezes que citarmos estas fontes deixaremos de explicitar as séries cronológicas.

O número da amostra por nós selecionada é significativo, basta fazermos a seguinte relação: se confrontamos 249 escravos da amostra com 639 ou 1.201 escravos registrados no censo de 1872 ou na matrícula de 1873 , teremos uma freqüência de $39 \%$ ou $21 \%$ respectivamente. Tanto um quanto outro indicador nos parecem bastante representativos, mesmo se temos em mente que estes dados foram trabalhados ao longo de quase 30 anos (1860 a 1888). Reforçando nosso argumento de natureza metodológica, se cruzamos as duas fontes - o número de escravos registrados no censo de $1872 \mathrm{com}$ as escrituras de compra e venda efetivamente realizadas neste ano - encontramos 18 escravos de fato transacionados em 639 registrados no censo, ou seja, $2,8 \%$ do total. Se 
confrontarmos 18, em 1.201 escravos registrados na matrícula de 1873 , encontraremos um índice de 1,5\% do total. Um segundo critério seguido, além do critério acima, constituiu-se na escolha aleatória das folhas ímpares dos livros de notas, os quais seguiam uma série cronológica ano a ano. ${ }^{3}$

Uma pequena parcela de cativos $(6,0 \%)$ foi negociada depois de 1880. A grande maioria foi negociada nas décadas de 60 e 70 . É interessante observar que os compradores de escravos mantiveram atitudes similares em relação ao mercado local de compras e vendas nas décadas de 1860 e 1870, negociando um volume de escravos bastante parecido, se compararmos quantidades de uma e outra décadas. Esta oferta e demanda por escravos se realizou dentro da própria comarca de Bananeiras. Alguns poucos compradores e vendedores pertenciam às praças vizinhas, tais como Recife, Mamanguape, cidade da Paraíba, ou mesmo de termos vizinhos da Província do Rio Grande do Norte.

A historiografia sobre o comércio de escravos, a nível nacional, mostra um vigoroso comércio interprovincial neste período. Por outro lado, percebe-se que uma parcela representativa de escravos foi comercializada dentro da própria região de Bananeiras. Como explicar este fenômeno? ${ }^{4}$ Eram duas as nossas hipóteses iniciais baseadas na historiografia: a primeira, de que as lavouras açucareiras teriam sido severamente afetadas com o comércio de escravos; ${ }^{5}$ a segunda, de que teriam sido os pequenos proprietários de cativos os primeiros a venderem seus escravos para o tráfico interprovincial. ${ }^{6}$ Veremos a seguir tais hipóteses sendo testadas e antecipamos ao leitor que o resultado desta pesquisa se definirá por um terceiro caminho (ou como queira, uma terceira hipótese) ${ }^{?}$

A tabela 2 mostra o resultado de nossos dados. Trata-se do comércio de escravos analisado a partir das variáveis idade e sexo. No que diz respeito à variável idade, dividimos em três faixas etárias: as crianças entram na faixa de 0 a 14 anos; os adultos, na faixa de 15 a 40 anos e os velhos acima de 40 anos. ${ }^{8}$ Do total de escravos transacionados, quase a metade, $47 \%$, foi de mulheres; $53 \%$, foram homens (veja a nota 1 da tabela). Este resultado nos deixou surpresos, pois a historiografia aponta que a maior parte dos cativos comercializados no âmbito do tráfico interprovincial se constituía de homens. Como explicar então este comportamento diferenciado dos proprietários rurais da região foca- 
lizada em relação aos proprietários rurais do Centro-Sul? Como o leitor já deve ter percebido, o que está em questão é o objeto de estudo. O tema da escravidão no Brasil tem sido estudado ao longo dos anos através do recorte temático e metodológico (nos referimos aqui especialmente às fontes) que privilegia os grandes plantadores, particularmente àqueles ligados às grandes lavouras de café e açúcar. Só nos últimos anos têm aparecidos trabalhos que lidam com objetos novos e abordagens diversas. 9 A nossa discussão empírica define-se num âmbito de história local onde a historiografia brasileira se detêm de forma bastante secundária. ${ }^{10}$ Padecemos de um vício, que em algum momento teremos que parar para pensar, qual seja, o vício de "sobrecarregar" as categorias universalizantes. No nosso tema específico - comércio de escravos - a literatura pertinente lida com problemáticas que se configuram a um nível inter e intra-regional estabelecendo ligações com compradores de cativos das plantações de café. ${ }^{11} \mathrm{O}$ resultado desta pesquisa se apresenta como novo na medida em que esta região, tradicionalmente vista como decadente e em estagnação, apresenta um relativo vigoroso comércio de escravos de forma tão inusitada.

\section{TABELA 2}

O comércio de escravos em relação à idade e sexo, 1860-1888

\begin{tabular}{|c|c|c|c|c|c|c|}
\hline \multirow{3}{*}{$\begin{array}{l}\text { Escravos } \\
\text { Comercializados }^{(1)}\end{array}$} & \multicolumn{6}{|c|}{ Faixa Etária ${ }^{(2)}$} \\
\hline & \multicolumn{2}{|c|}{ Crianças } & \multicolumn{2}{|c|}{ Adultos } & \multicolumn{2}{|c|}{ Velhos } \\
\hline & $\begin{array}{l}\text { Freq. } \\
\text { Abs. }^{(3)}\end{array}$ & $\begin{array}{l}\text { Freq. } \\
\text { Rel. }^{(4)}\end{array}$ & $\begin{array}{l}\text { Freq. } \\
\text { Abs. }^{(3)}\end{array}$ & $\begin{array}{l}\text { Freg. } \\
\text { Rel. }^{(4)}\end{array}$ & $\begin{array}{l}\text { Freq. } \\
\text { Abs. }^{(3)}\end{array}$ & $\begin{array}{l}\text { Freq. } \\
\text { Rel. }^{4}\end{array}$ \\
\hline Homens & 36 & 29,3 & 80 & 65,0 & 7 & 5,7 \\
\hline Mulheres & 41 & 37,2 & 62 & 56,4 & 7 & 6,4 \\
\hline
\end{tabular}

FONTES: Escrituras de Compra e Venda de Escravos, localizadas nos livros de Notas.

(1) A soma total dos escravos comercializados: 123 homens +110 mulheres $=233$. Participaçáo relativa de homens $e$ mulheres: $123 / 233=53 \%$ e $110 / 233=47 \%$, respectivamente.

(2) A classificaçăo crianças, adultos evelhos obedece ao critério: $0 \mathrm{a} 14$ anos, 15 a 40 anos e acima de 40 anos, respectivamente.

(3) Os escravos que nåo apresentaram registro de idade foram expurgados.

(4) A soma das frequências relativas perfazem $100 \%$ na linha horizontal,e as absolutas: $36+80+7=123$ (homens), $41+$ c $62+7=110$ (mulheres) também na horizontal. 
Voltando aos nossos dados: dizíamos que as mulheres cativas constituíam quase a metade desta população, e enfatizávamos este fato como algo diverso da imagem corrente sobre o comércio de escravos. Agora, gostaríamos que nosso leitor expurgasse as variáveis de idade relativas às crianças e aos velhos, e observasse os seguintes resultados: $27 \%$ (62/233), ou seja, 62 escravas no total de 233 escravos comercializados, se constituía só de mulheres, contra uma participação masculina de $34 \%$ (80/233) em iguais condições de idade produtiva. O que também nos chamou atenção foi o fato de que escravos bastante jovens (crianças) faziam parte de forma significativa deste comércio. As crianças escravas participavam na proporção de $33 \%(36+41 / 233)$ no total da compra e venda. Os meninos escravos entram na proporção de $29,3 \%$ (36/123), enquanto as meninas escravas 37,2\% (41/110). Alertamos ao leitor que o denominador 233 corresponde ao total de escravos homens e mulheres (crianças, adultos e velhos) comercializados. De maneira semelhante, o denominador 123 corresponde tão somente à soma dos escravos do sexo masculino (crianças, adultos e velhos) transacionados. $\mathrm{O}$ denominador 110 corresponde ao total das mulheres escravas comercializadas (crianças, adultas e velhas). Nesta perspectiva, configura-se um retrato da escravidão bem diferente do que estamos acostumados a imaginar. Fora das plantations tradicionais, dos grandes plantéis e das grandes propriedades, havia todo um mundo diverso do nosso imaginário atinente à escravidão. Este mundo, do qual falamos, era um mundo onde os escravos não se constituíam em parte majoritária da população, muito pelo contrário, eram parte estatisticamente registrada enquanto minoritária. Por outro lado, seus senhores mantinham algo em comum com seus pares do eixo Centro-Sul do país, no que diz respeito às suas atitudes, na medida em que compravam e vendiam escravos, e diferentes, na medida em que, ao contrário do que a historiografia costuma afirmar, ou melhor, ignorar, os compravam e vendiam entre si. Compravam e vendiam não só homens escravos como também, em boa proporção, mulheres e até crianças. Qual o sentido desta atitude? Infelizmente a resposta a esta pergunta transcende às fontes coligidas por nós. A solução deste enigma se dará no corpo de futuros trabalhos onde outros historiadores sistematizarão novas fontes de maneira mais exaustiva. Por enquanto nos contentaremos com nossa resposta aproximativa que segue. 


\section{TABELA 3}

Composição sexual de escravos nos diversos setores $d a$ vida econômica no Censo de 1872 (Município de Bananeiras)

\begin{tabular}{lcccccccccc}
\hline Sexo & Agri. & $\%$ & Dom. & $\%$ & s/Prof. & $\%$ & Outros & $\%$ & Total & $\%$ \\
\hline Homem & 202 & 32,0 & 55 & 8,6 & 60 & 9,3 & 23 & 3,6 & 340 & 53,2 \\
Mulher & 120 & 18,8 & 78 & 14,2 & 70 & 11,0 & 31 & 4,9 & 299 & 46,8 \\
\hline TOTAL & 322 & 50,4 & 133 & 20,8 & 130 & 20,3 & 54 & 8,5 & 639 & 100,0 \\
\hline
\end{tabular}

FONTE: BRASIL-DGE. I Recenseamento da População do Brasil a que se procedeu no dia $1^{\circ}$ de agosto de 187221 vols., Rio de Janeiro, Typ. de Leuzinger \& Filhos, 1873-76.

Através do censo de 1872, pode-se inferir algumas idéias a respeito deste problema. A tabela 3 mostra o registro de escravos no município de Bananeiras. Foram contempladas duas paróquias: a de Bananeiras e a de Araruna. Gostaria de lembrar ao leitor que estes dados estão subestimados, se confrontamos com o registro quantitativo da matrícula de $1873 .{ }^{12}$ Contudo, a despeito do sub-registro, presumimos que as proposições inferidas da leitura dos dados têm a mesma validade em termos proporcionais: para tanto basta operar uma projeção dos valores relativos (em percentuais) nos números em valores absolutos da matrícula.

Feito esta ressalva, procedamos com a leitura dos vestígios. O sentido da compra de escravos pode ser entendido, nos limites do município por nós estudado, através da tabela 3, acima referida. Ela mostra-nos a composição sexual dos escravos nos diversos setores da vida econômica da região focalizada. $\mathrm{Na}$ área reservada às profissões agrícolas (da tabela do censo) $)^{13}$ constam as categorias lavradores e criadores. $\mathrm{Na}$ categoria criadores, os recenseadores não registraram nenhum escravo na atividade da pecuária. Este não-registro configura uma certa dose de, digamos, irrealismo. Certamente os cativos lavradores, domésticos e os "sem profissão" desenvolviam as mais diversas tarefas ao mesmo tempo. Desde o trato com a terra, passando pelas tarefas ligadas à criação de animais de leite e de corte, até funções domésticas, em se tratando especialmente de pequenas propriedades agrícolas nas quais a produção do excedente eventualmente era trocada no mercado. Agora, sem mais 
delongas, voltemos às evidências: 50,4\%, (322/639), dos cativos estavam alocados nas atividades agrícolas. Ou seja, 18,4\% (120/639) das mulheres e $32 \%(202 / 639)$ dos homens. Um outro grupo de escravos, $20,8 \%$ (133/639), lidavam com atividades ditas domésticas. Um terceiro grupo, registrado enquanto escravos "sem profissão", correspondeu a $20,3 \%$ (130/639) da população mancípia. Finalmente, o quarto e último grupo: desta feita, concentramos várias categorias do censo em uma só, pois eram estatisticamente pouco representativas, e denominamo-lo (o grupo) de "outros". Neste, encontramos costureiras, trabalhadores que labutavam com metais, madeiras, couros e peles e com vestuário. No subgrupo (vestuário), os planejadores do censo tinham em mente os cativos alfaiates quando se referiam a este. A população deste derradeiro grupo que nós batizamos de "outros" participava na proporção de $8,4 \%$ (54/639).

Portanto, sugerimos, em resposta àquelas nossas inquietações, quais sejam, de entender o sentido da compra de escravos naquele paradouro tão distante dos pólos dinâmicos, uma solução aproximativa com agudo sentido de verossimelhança: o registro censitário se constitui neste momento uma possibilidade para entender em parte o problema. A julgar pela tabela do censo sobre população em relação às profissões, conclui-se que boa parte da população cativa estava sendo comercializada para executar tarefas ligadas às lides agrícolas em primeiro lugar; em segundo lugar, desenvolvia tarefas domésticas; e em último lugar, em termos estatísticos, desenvolvia atividades manuais, mecânicas, tarefas que lidavam com couros, peles, metais, madeiras, vestuário, etc.

Na tabela 4 , temos a distribuição de freqüência dos compradores de escravos em relação ao tamanho dos plantéis. ${ }^{14}$. São 8 classes com intervalos fechados que se referem ao tamanho dos plantéis por ocasião da abertura dos inventários e nảo, como o leitor poderia presumir, no instante da compra e venda. No nosso trabalho, consideramos pequenos proprietários aqueles que possuíam de 1 a 3 escravos, médios proprietários, aqueles que possuíam de 4 a 9 , e grandes, aqueles que detinham além de 10 escravos. ${ }^{15}$ A coluna do meio registra a freqüência ou a quantidade dos compradores de cativos em relação ao número de vezes que estes freqüentam cada classe (tamanho dos plantéis). Na colu- 


\section{TABELA 4}

Distribuição de freqüência dos compradores de escravos em relação ao tamanho dos plantéis

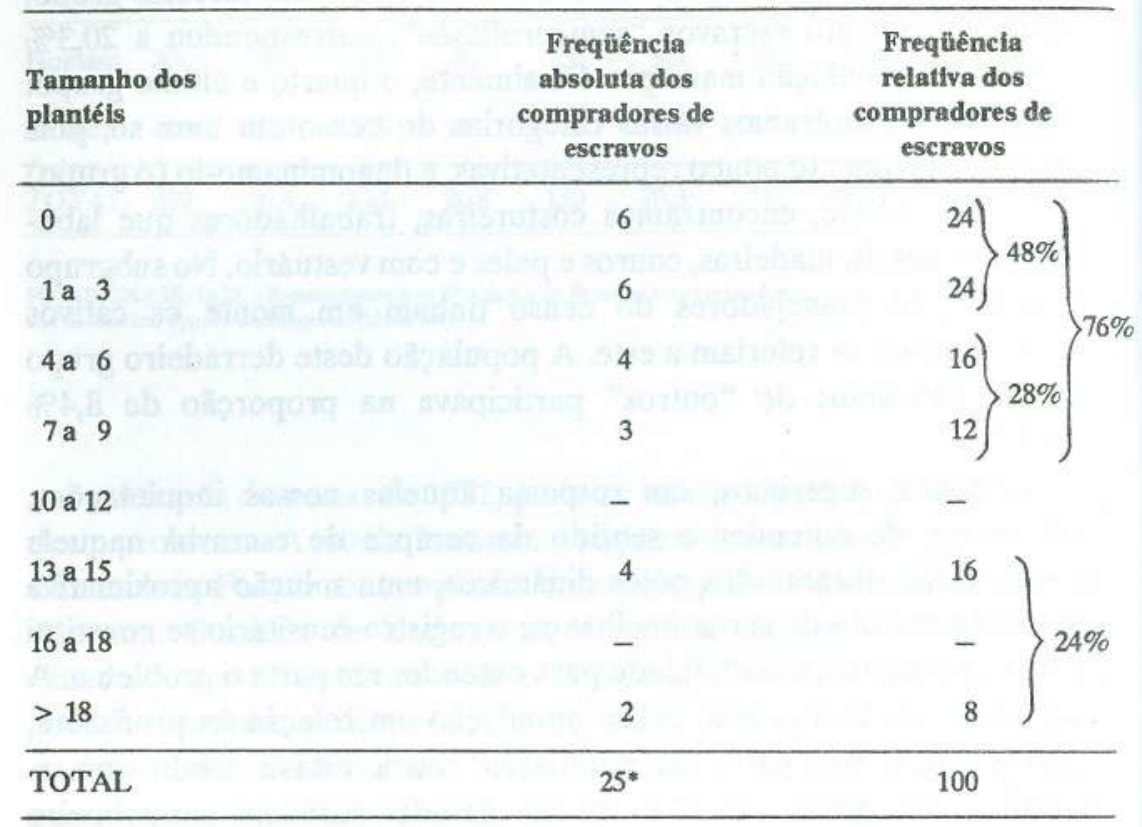

FONTES: Dados extraídos do cruzamento dos inventários com as escrituras de compra evenda de escr avos e arquivo nominal. O tamanho dos plantéis se refere à época da abertura dos inventários e nâo à época da compra e venda.

- Este número é menor do que o número total de compradores de escravos selecionados $(=35)$, porque alguns deles só tiveram seus inventários abertos após a aboliçăo e, estes foram expurgados da amostra final.

na da direita o leitor verá a freqüência dos compradores de escravos em termos relativos (percentuais). Na ultima linha no sentido horizontal, aparecem dois números, 25 e 100, que equivalem à soma das freqüências absoluta e relativa, respectivamente. Na quinta e sétima classes, aparecem apenas um hífen indicativo de que não temos dados para apresentar, o que não invalida a demonstração e o resultado dos nossos dados. Os adquirentes de cativos - $24 \%$ - não possuíam escravo algum por época da abertura de seus inventários: eram proprietários inventariados que faleceram antes da abolição da escravatura e que tinham liquidado seus bens semoventes antes desta data. Outros, com igual freqüência - $24 \%$ 
- eram também compradores de escravos, contudo pertenciam à classe dos pequenos proprietários de plantéis que possuíam de 1 a 3 cativos. Mais adiante, observa-se que os médios senhores possuidores de plantéis que variavam entre 4 e 9 cativos participaram com freqüência de $28 \%$ $(16 \%+12 \%)$ e os grandes proprietários que possuíam 10 ou mais escravos atuavam com uma freqüência em torno de $24 \%(16 \%+8 \%)$.

$\mathrm{O}$ que se pode concluir da demonstração de tais vestígios? Algumas páginas atrás, nós propusemos que o sentido das atitudes dos senhores de escravos da comarca de Bananeiras poderia ser em parte compreendida a partir do primeiro registro censitário. Agora, a nossa proposição é que o cruzamento das escrituras de compra e venda com os inventários post-mortem possa nos fornecer pistas complementares as quais nos conduzam de novo a uma solução daquele problema com maior grau de plausibilidade. Na primeira parte da pergunta, tentamos responder: 0 quê tais escravos estavam fazendo? Agora, tentaremos responder: quem eram estes senhores em termos de riqueza servil? Ou melhor, eram senhores de grandes ou pequenos plantéis? Em seguida, nos propomos a responde: quem eram estes senhores em termos de riqueza rural? Isto é: que lavouras eles plantavam?

A partir da apresentação dos dados acima, podemos propor a seguinte idéia: a maior parte $-76 \%(48 \%+28 \%)$ - dos compradores de escravos eram pequenos e médios proprietários de plantéis que variavam de 1 a 9 cativos. Esta imagem que desponta destas evidências se diferencia da outra, retratada pela historiografia, que mostra barões e grandes proprietários comprando cativos para suas vastas plantations. A visão ou idéia evocada destes dados traça uma representação do comércio de escravos bem diversa daquela que estamos habituados a ter. Um segmento da historiografia apontaria este comportamento enquanto tal como não racional do ponto de vista econômico. Não entraremos no mérito desta questão. $\mathrm{O}$ nosso método deverá ser outro. Não partiremos aprioristicamete de supostas leis gerais (universalizantes) da história econômica para explicar o nosso fenômeno em foco. Na medida do possível, trabalharemos os dados de tal forma que, na proporção que as evidências sejam expostas, colocaremos aí as prováveis, ou ainda, verossímeis hipóteses explicativas a partir dos vestígios colecionados por nós. 
TABELA 5

Classificação das ocupações dos compradores de escravos

\begin{tabular}{|c|c|c|c|}
\hline Atividades & $\begin{array}{c}\text { Frequêêncla } \\
\text { absoluta }\end{array}$ & $\begin{array}{l}\text { Freqüência } \\
\text { relativa (\%) }\end{array}$ & \\
\hline Mandioca/gado & 11 & 38 & \multirow{2}{*}{$62 \%$} \\
\hline Algodăo/mandioca/gado & 7 & 24 & \\
\hline $\begin{array}{l}\text { Café/cana-de-açúcar/ } \\
\text { algodão/mandioca/gado }\end{array}$ & 2 & $7)$ & \multirow{3}{*}{$38 \%$} \\
\hline $\begin{array}{l}\text { Cana-de-açúcar/ } \\
\text { mandioca/gado }\end{array}$ & 4 & 14 & \\
\hline $\begin{array}{l}\text { Cana-de-açúcar/algođão/ } \\
\text { mandioca/gađo }\end{array}$ & 5 & $17)$ & \\
\hline TOTAL & $29^{*}$ & 100 & \\
\hline
\end{tabular}

FONTES: Dados extraidos do cruzamento dos inventários e das escrituras de compra evenda de escravos e arquivo nominal. - 4 compradores não apresentam indicios do tipo de atividade possivelmente desersvolvida. 2 inventários foram expurgados, porque só foram abertos muito além do perfodo retratado por nóa.

$\mathrm{Na}$ tabela 5, referente à classificação das ocupações dos compradores de escravos, lê-se 5 classes de compradores a partir dos tipos de lavouras plantadas. Devemos esclarecer o leitor que, na documentação reunida, o cultivo dos gêneros alimentícios e agrícolas, de um modo geral, era realizado de forma consorciada. Isto é, os plantadores de cana-deaçúcar e algodão cultivavam simultaneamente roças de mandioca e pomares de diversas frutas regionais. Estas altimas aparecem de forma explícita mais raramente na documentação. Há alusão ao cultivo de milho e arroz de forma bastante pouco freqüente. $\mathrm{O}$ gado e a mandioca são itens presentes, pode-se assim dizer, em $100 \%$ dos casos. É possível entender o hábito alimentar ainda hoje tão arraigado e forte do nordestino em relação ao uso da tapioca feita com farinha de mandioca e leite de coco, mais comum na região do litoral, e a tapioca feita com farinha de mandioca e leite de gado, comum à medida que se adentra em direção ao sertão. Analisando os dados, encontramos $62 \%(24 \%+38 \%)$ dos compradores de cativos cultivando lavouras tradicionalmente consideradas de pobres, ou pelo menos, desenvolvendo atividades consideradas menos nobres, tais como, algodão, mandioca e gado. Um 
segmento equivalente a $38 \%(17 \%+14 \%+7 \%)$ dos compradores cultivavam também, além das atividades mandioca e gado, - o regionalmente considerado produto "rei" - a cana-de-açúcar. O café aparecera na terceira classe associado à cana; porém, será no último decênio do século $\mathrm{XIX}$ e especialmente nas duas primeiras décadas do século XX que fará enriquecer algumas poucas famílias da região. Ele se tornará uma cultura de cultivo popular já em princípio deste século e desaparecerá, em razão de uma praga que dizimará os cafezais da região, por volta de 1923.

Portanto, retomando a questão de qual o sentido do comércio de escravos do ponto de vista dos compradores, pode-se concluir que, de uma maneira geral, grande parte dos pequenos e médios proprietários, como também, aqueles que desenvolviam atividades rurais tidas como menos nobres, constituíam um segmento bastante representativo no que diz respeito à demanda por cativos.

TABELA 6

Distribuição de freqüência do tamanho dos plantéis em relação aos vendedores de escravos

\begin{tabular}{|c|c|c|c|c|}
\hline $\begin{array}{l}\text { Tamanho dos } \\
\text { plantéis }\end{array}$ & & $\begin{array}{c}\text { Freqüência absoluta } \\
\text { de vendedores } \\
\text { de escravos }\end{array}$ & $\begin{array}{r}\text { Freqüêncis } \\
\text { dos vend } \\
\text { de esc }\end{array}$ & $\begin{array}{l}\text { relativa } \\
\text { dores } \\
\text { vos }\end{array}$ \\
\hline 0 & & 7 & 23,3 & \multirow{4}{*}{$76,6 \%$} \\
\hline 1 a 3 & & 11 & 36,6 & \\
\hline 4 a 6 & & 4 & 13,3 & \\
\hline 7 a 9 & , & 1 & $3,3 \int^{10}$ & \\
\hline 10 a 12 & & - & - & \\
\hline 13 a 15 & & 3 & 10,0 & \\
\hline 16 a 18 & & 1 & 3,3 & $23,3 \%$ \\
\hline$>18$ & & 3 & 10,0 & \\
\hline TOTAL & & 30 & 100,0 & \\
\hline
\end{tabular}

FONTE: Dados extraidos do cruzamento de irventários e escrituras de compra e venda de escravos e arquivo nominal. O tamanho dos plantéis se referem à época da abertura do inventário e nảo à época da compra e venda. 
Agora, gostaríamos de analisar a compra e venda de cativos a partir da ótica da venda relativa aos proprietários que se desfaziam de seus bens semoventes. Para tanto, apresentamos dados resultantes do cruzamento de inventários post-mortem com as escrituras de compra e venda e nosso arquivo nominal.

A tabela 6 é bastante semelhante à tabela 4 , anteriormente apresentada, só que diz respeito à distribuição de frequiência do tamanho dos plantéis em relação aos vendedores de escravos. Na coluna da esquerda, estão distribuídos os vários tamanhos de plantéis. Na coluna do meio, está a distribuição em números absolutos da freqüência de vendedores de escravos. Na coluna da direita, apresentamos os dados em termos percentuais. Observamos que $23,3 \%$ dos vendedores não possuíam escravos. Você poderá se sentir intrigado com o aparente paradoxo: como poderiam vender escravos se não os possuíam? A nossa idéia é que uma parte dos senhores liquidaram seus bens semoventes antes da abertura de seu inventário. Esta idéia nos parece bastante plausível. Pequenos proprietários que possuíam de 1 a 3 escravos participaram vendendo escravos na proporção de $36,6 \%$. Os médios, participaram na proporção de $16,6 \%$, e os grandes, na proporção de $23,3 \%$. Se somarmos as freqüências dos pequenos e médios proprietários mais os que não tinham nenhum escravo, notaremos que uma ampla margem de $76,6 \%$ deles participaram da venda de cativos, contra uma participação dos grandes de $23,3 \%$.

A tabela 7 estabelece classes em relação às ocupaçōes dos vendedores de mancípios. Tanto os plantadores de culturas ditas tradicionais quanto aqueles plantadores de culturas vistas como de menor rentabilidade concorriam com relativa igualdade no mercado de escravos local. Aqueles que consorciavam cana-de-açúcar com outras plantações, como algodão e mandioca, e criavam gado, atingiam a participação de $48 \%$ em relação ao total dos vendedores de escravos. Aqueles que consorciavam algodão, mandioca, gado mais aqueles que consorciavam apenas mandioca e gado, mais aqueles que consorciavam tabaco e café, participavam numa proporção de $52 \%$ em relação ao total dos vendedores. 
TABELA 7

Classificação das ocupaçōes dos vendedores de escravos

$\left.\begin{array}{lcc}\hline \text { Atividades } & \begin{array}{c}\text { Freqüência } \\ \text { absoluta }\end{array} & \begin{array}{r}\text { Freqüência } \\ \text { relativa (\%) }\end{array} \\ \hline \text { Tabaco/café } & 1 & 3,0 \\ \text { Manđioca/gado } & 8 & 24,2 \\ \begin{array}{l}\text { Algodão/mandioca/gado } \\ \text { Café/cana-de-açúcar/ } \\ \text { algodão/mandioca/gado }\end{array} & 8 & 24,2\end{array}\right) 52 \%$

FONTES: Dados extraídos do cruzamento dos inventários e escrituras de compra e venda de escravos e arquivo nominal.

\section{Conclusões gerais}

Analisando o comportamento do mercado local do ponto de vista da demanda e da oferta, relacionando-o com as ocupações sócioeconômicas e com os tamanhos dos plantéis dos compradores e vendedores de éscravos, temos as conclusões que seguem.

Primeiro, no que diz respeito às ocupações sócio-econômicas, tanto os compradores quanto os vendedores participavam do mercado de compra e venda de cativos de uma forma não-substancial nem significativamente diferente. Os plantadores de culturas ditas nobres e tradicionais como a cana-de-açúcar aparecem consorciando-a com as culturas ditas de pobres e de menor rentabilidade, como algodão, mandioca e criando gado. Este segmento de plantadores atuava na compra na proporção de $38 \%$ contra $48 \%$ daqueles que atuavam na venda. Segundo, em relação ao tamanho dos plantéis, tanto os pequenos e médios proprietários concorriam com participação surpreendente- 
mente semelhante tanto do lado da demanda, $76 \%$, quanto da oferta, $76,6 \%$. Os grandes proprietários também participavam de forma surpreendentemente parecida, algo em torno de $24 \%$ atuavam enquanto compradores contra $23,3 \%$ como vendedores.

A partir destes dados, não nos afiliamos à posição de que o impacto do comércio interno de escravos foi violento na economia açucareira nordestina, nem à de que os proprietários de escravos pequenos e marginais teriam sido os primeiros a venderem seus cativos ao eixo Centro-Sul do país. O nosso argumento é que, se houve um impacto na economia açucareira nordestina com comércio inter-regional de escravos, outras economias também sofreram um certo impacto, do ponto de vista do comportamento do mercado local de escravos. Não podemos aqui, no âmbito deste trabalho, quantificar as perdas destas economias. Entretanto, a imagem recriada a partir destes dados retrata um segmento de pequenos e médios proprietários de escravos como também de senhores plantadores de algodão, mandioca e criadores de gado que participavam da compra e venda de cativos de forma mais ativa do que os grandes plantadores. Para além da idealização de um mundo rural oitocentista povoado por senhorzinhos e sinhazinhas com suas casas grandes e senzalas, habitado por imensos plantéis de escravos a produzir açúcar, havia também um outro mundo habitado por senhores proprietários de pequenos e médios plantéis que detinham conjuntamente uma grande fatia da escravaria da comarca e plantavam culturas consideradas de pouco prestígio e status social.

\section{Notas}

1. ANDRADE, Manuel Correia de. A Terra e o Homem no Nordeste. 4.ed., São Paulo, Ciências Humanas, 1980. p.132-41.

2. STEIN, Stanley J. Vassouras. A Brazilian Coffee County, 1850-1900. 2.ed. Princeton, Princeton University Press, 1985. p.65-7; VIOTTI DA COSTA, Emflia. Da Senzala à Colônia. São Paulo, Ciências Humanas, 1982. p.115-6; CONRAD, Robert. Os Últimos Anos da Escravatura no Brasil. Rio de Janeiro, Civilização Brasileira, 1978. p.63-87; TOPLIN,Robert B. The Abolition of Slavery in Brazil. New York, 1972. p.10.

3. Os Livros de Notas selecionados por nós estão localizados no Arquivo do Cartório do Segundo Ofício da Comarca de Bananeiras. O Arquivo do Cartório de Primeiro Ofício não possui este tipo đe documentação, concentrando apenas documentos referentes aos processos criminais. As séries levantadas referem-se aos anos: 1860 , $1861,1865-1867,1867-1877,1876-1879,1879-1884,1884-1890$.

4. Vale notar, como observou o prof. Robert Slenes que "os dados sobre sexo e idade dos escravos vendidos são coerentes com o que se esperaria de um mercado puramente local: haveria uma maior proporção de mulheres e crianças em comparação com o 
mercado de Campinas-São Paulo e Vassouras-Rio de Janeiro, etc., mercados importadores". Mais adiante ele continua: "a bibliografia năo nega a existência de transferências locais de escravos, ela simplesmente não dá importância a isto e praticamente não fala sobre o assunto". Sobre o problema da documentação de compra e venda de escravos, das procurações e subestabelecimentos sucessivos, veja: SLENES, Robert W. "Grandeza ou Decadência? O Mercado de Escravos e a Economia Cafeeira da Província do Rio de Janeiro, 1850-1888". In Brasil: Historia Econômica e Demográfica. Săo Paulo, FIPE/USP, 1986. p.103-57.

5. TOPLLIN in The Abolition [...] foi o autor que mais enfatizou esta posição, p.19. Eisenberg, Peter L. Modernização sem Mudança. Rio de Janeiro, Paz e Terra, 1978. p.174-7. O autor comenta de passagem sobre o tráfico interprovincial como um fator entre outros que contribuiu para a abolição gradual no Nordeste, e assevera: "Os cultivadores de cana vendiam seus escravos em pequenos lotes, cada ano, para cobrir os débitos com seus agentes de Recife, e 760 escravos saíram em média por ano, legalmente, da Província.

6. KLEIN, Herbert. "The Internal Slave Trade in Nineteenth Century Brazil: A Study in Slave importations into Rio de Janeiro in 1852", H.A.H.R., LI, n.4 (november, 1971), p.567-85, especialmente, p.583-5. Argumentou que a importância do tráfico intraregional foi muito maior que o tráfico inter-regional no suprimento de mão-de-obra para as plantações de café. Afirma que a maioria dos escravos no tráfico inter-regional não teriam, vindo das plantaçōes de cana do Nordeste; GALLOWAY, J.H. "The Last Years of Slavery in Sugar Plantations of Northeastern Brazil", H.A.H.R, LI, n.4 (november, 1971), p.589. Argumenta que os proprietários de escravos donos de pequenos plantéis e plantadores marginais teriam sido os primeiros a venderem seus cativos aos plantadores do eixo Centro-Sul. CONRAD em seu trabalho supracitado encontrou que os políticos nordestinos no congresso estavam mais dispostos a votar a favor da abolição gradual que os políticos do Centro-Sul. Atribui esta atitude à importância declinante da escravidão no Nordeste. Mostra que esta pouca importância se deveu a dois fatores: a incapacidade da população escrava de se reproduzir tão rapidamente quanto a população livre, e a crescente e contínua sangria de mão-de-obra escrava através do tráfico interprovincial. Veja especialmente as tabelas números 21,24 e 25 , p.362-4. SLENES, Robert W. The Demography and Economics in Brazilian Slavery: 1850-1888. Tese de doutoramento. Stanford University, 1976, p.120-233 para capítulos III e IV. Neste último, o autor identifica as áreas exportadoras e importadoras no tráfico inter e intra-regional, concluindo: "The great majority of bondsmen who were sold in the inter and intraregional trades in Brazil did not como from the plantations, but from the urban areas or regions of non-plantations agriculture".p.214.

7. O que queremos enfatizar neste trabalho focalizando o mercado de escravos do ponto de vista estritamente local é que os pequenos e médios proprietários participavam de forma mais ativa que os proprietários de grandes plantéis.

8. Este critério é o mais usual.

9. Pensamos, por exemplo, nos trabalhos sobre escravidão urbana: ALGRANTI, Leila Mezan. O Feitor Ausente. Rio de Janeiro, Petrópolis, 1988. SILVA, Marilene Rosa Nogueira. Negro na Rua. São Paulo, Hucitec, 1988. AZEVEDO, Célia Maria Marinho. Onda Negra, Medo Branco. São Paulo, Paz e Terra, 1987. CHALOUB, Sidney. Visões de Liberdade. São Paulo, Cia. das Letras, 1990. LARA, Silvia. Campos da Violência. São Paulo, Paz e Terra, 1988. Estes dois últimos autores trabalham perspectivas interessantes sobre compra e venda de cativos, especialmente a percepção dos negros de brechas e espaços do sistema na sua vida cotidiana.

10. Há um interessante estudo sobre história local que focaliza lavradores pobres na crise do trabalho escravo. Veja: CASTRO, Hebe Maria Mattos de. Ao Sul da História. São Paulo, Brasiliense, 1987. A autora percebe assim o problema: "Sem a agricultura desenvolvida em pequenas plantaçőes e voltada exclusivamente para o mercado 
interno, a economia agro-exportadora dominante no Brasil durante quatro séculos não teria condição de se sustentar, e muito menos de existir. Nem por isto os historiadores têm o hábito de estudar o assunto. O pequeno produtor, homem livre e pobre, ficou relegado a um lugar menor, secundário, ao sul da história".

11. Nos referimos aqui aos autores citados nas notas 2 e 5 .

12. Conforme SLENES demonstra em sua tese de doutoramento à p.57, o registro censitário de 1872 e o registro da matrícula de 1873 apresentam uma discrepância significativa, especialmente, no que se refere à província da Paraıba. O sub-registro censitário atinge a cifra de $27 \%$ em relaçăo à matrícula.

13. Nos referimos aqui às tabelas do censo de 1872 intituladas: "População considerada em relação às profissões". p. $36 \mathrm{e} 39$.

14. Em relação ao método proposto por nós sobre a distribuição de frequüência das tabelas 4, 5, 6 e 7, o leitor poderá indagar-se sobre a influência dos donos de plantéis pequenos e médios - segmento majoritário - projetando daí, uma discrepância dos resultados gerais das tabelas a favor dos pequenos e médios. Entretanto, tendo em vista que a grande maioria, cerca de $80 \%$, dos lotes de compra e venda de escravos se constituíram de 1 e apenas 1 escravo, tal suposição, torna-se inválida, ou pelo menos atenuada.

15. A divisão em classes com intervalos fechados đe 3 năo foi uma decisão arbitrária: o método constituiu-se do somatório de todos os indivíduos escravos registrados nos inventários post-mortem, dividido pelo somatório da quantiđade de inventários, resultando na média 2,9. Em seguida, arredondamos para 3 . Alertamos ao leitor que este indicador revela um índice de propriedade escrava por inventário e não a relação escravo/propriedade declarada. 